\title{
REDUÇÃO DA COBERTURA DAS VACINAS TRÍPLICE E TETRA VIRAL E O AUMENTO DA INCIDÊNCIA DE CASOS DE SARAMPO NO BRASIL ENTRE 2014 E 2019
}

\section{COVERAGE REDUCTION OF TRIPLE AND TETRA VIRAL VACCINES AND THE INCREASING INCIDENCE OF MEASLES CASES IN BRAZIL BETWEEN 2014 AND 2019}

Mariana Schmitt Pereira Cardoso, Rafaela Macedo Soares ${ }^{*}$, Fernanda Carolina Menechini Rocha, Stefany Cristina Cherubim, Beatriz Pimenta Vinha, Ana Paula Uber.

UNINGÁ - Centro Universitário Ingá, Maringá, PR, Brasil.

*rafaela.ms1996@gmail.com

\section{RESUMO}

O sarampo é uma patologia grave, altamente contagiosa, causada por vírus da família Paramyxoviridae. Um único indivíduo infectado pode transmitir para, em média, 15 pessoas ao tossir, espirrar e falar. Os sintomas incluem febre alta, tosse seca, conjuntivite, dor muscular e de garganta, cansaço excessivo, manchas vermelhas que se espalham na pele, sem relevo e que não coçam, além de manchas brancas na mucosa oral. Casos mais graves podem evoluir para um quadro de encefalomielite aguda disseminada. O tratamento consiste apenas em suporte clínico, sendo a prevenção por meio da imunização, o melhor método de combate à doença. Com esse intuito, foram criadas as vacinas tríplice viral e tetra viral. Em 2016 a doença foi considerada erradicada do país, contudo, com a queda da cobertura vacinal (CV), juntamente com a circulação do vírus decorrente de movimentos migratórios, os casos de sarampo voltaram a crescer no Brasil. Este trabalho tem como objetivo analisar a queda da CV entre os anos de 2014 e 2019 e o aumento da incidência de sarampo nos estados brasileiros ao longo desse período, bem como realizar um levantamento sobre os fatores relacionados a essa redução. Trata-se de um estudo epidemiológico, descritivo e quantitativo. A população do estudo abrange os casos notificados e/ou confirmados de sarampo no país disponibilizados pelos boletins epidemiológicos das Secretarias de Saúde das Unidades Federadas. Os dados de cobertura das vacinas tríplice e tetra viral foram extraídos do Departamento de Informática do Sistema Único de Saúde (DATASUS). O levantamento dos dados indicou que a cobertura de ambas vacinas foi superior a $90 \%$ em 2014, e os casos confirmados de sarampo foram raros nos anos seguintes. A partir de 2015, a cobertura da vacina tetra viral sofreu significativa redução e ficou em torno de 34\% em 2019. Já a CV da primeira dose da tríplice viral reduziu de 112,8\% em 2014, para $92,65 \%$ em 2019 , enquanto a segunda dose reduziu de $92,88 \%$ para $81,12 \%$ nesse mesmo período. Em 2018, os casos de sarampo, que eram raros, aumentaram significativamente, chegando a 18.203 casos em 2019. É imprescindível, para o controle e redução dos casos de sarampo no Brasil, que a vacinação da população-alvo seja realizada de maneira eficiente. No entanto, o que se observou ao longo do período analisado, é que a CV esteve abaixo do 
recomendável pela Organização Pan-Americana da Saúde, que seria de 95\% da população alvo. Salienta-se uma limitação do estudo quanto aos dados disponibilizados pelo Ministério da Saúde, pois dependem do correto preenchimento das notificações compulsórias do sarampo e do registro das vacinações nos bancos de dados.

Palavras-chave: Doenças virais. Imunização. Política em Saúde Pública. Sarampo. Vacinação. 